The relationship between trade openness and economic growth: Some new insights on the openness measurement issue

\author{
Marilyne Huchet-Bourdon, Chantal Le Mouël, Mariana Vijil \\ SMART LERECO, AGROCAMPUS OUEST, INRA, 35000, Rennes, France
}

\begin{abstract}
Summary :
Empirical results on the links between trade openness and economic growth often suggest that, in the long run, more outward-oriented countries register better economic growth. However, a similar level of trade openness can hide different types of trade structures. The aim of this paper is to enrich the way of measuring trade openness taking into account two different dimensions of countries' integration in world trade: export quality and export variety. Based on the estimation of an endogenous growth model on a panel of 169 countries between 1988 and 2014 using a Generalized Method of Moments estimator, our results confirm that countries exporting higher quality products and new varieties grow more rapidly. More importantly, we find a non-linear pattern between the export ratio and the quality of the export basket, suggesting that openness to trade may impact growth negatively for countries which are specialized in low quality products. A non-linear relationship between exports variety, the export ratio and growth is also found, suggesting that countries increasing their exports will grow more rapidly after reaching a certain degree of the extensive margin of exports.
\end{abstract}

Key words: growth, trade openness, quality, variety, extensive margin, GMM, dynamic panel model.

JEL classification: F1, F4, O1 


\section{$1-$ INTRODUCTION}

Empirical evidence tends to show that in the long-run more outward-oriented countries register higher economic growth (Sachs and Warner, 1995; Edwards, 1998; Frankel and Romer, 1999; Dollar and Kraay, 2004; Lee et al., 2004, Freund and Bolaky, 2008, and Chang et al., 2009, among others). According to some authors, however, most of this work suffer from, at least, two serious shortcomings that make their results questionable: the way trade openness is measured and the retained estimation methods (Rodriguez and Rodrik, 2001, for instance).

Many different measures of trade openness have been proposed and used in empirical analyses of the relationship between openness and growth: measures based on trade restrictions/distortions (e.g., Pritchett, 1996; Harrison 1996; Edwards, 1998; Yanikkaya, 2003), "qualitative" indices aimed at classifying countries according to their trade and global policy regime (such as the 1987 World Development Report outward orientation index or the openness indices proposed by both Sachs and Warner, 1995, and Wacziarg and Welch, 2003), or outcome-based measures based on trade flows (such as the trade dependency ratio, see, e.g., Frankel and Romer, 1999; Irwin and Tervio, 2002; Frankel and Rose, 2002; Dollar and Kraay, 2004; Squalli and Wilson, 2011). These various measures relate to different definitions of openness: from trade policy or global policy orientation to the wider view that the outward orientation of a country depends not only on its policy orientation but also on a set of non-policy factors (such as geography and infrastructure for instance).

In this paper, we focus on the widest outcome-based definition of openness. Our aim is to contribute to the ongoing debate on the growth effect of trade by arguing that trade openness is a multidimensional concept that cannot be summarized to a single measure such as the commonly used trade dependency ratio. Thus, following recent developments in growth theory and in international economics, we propose a more comprehensive way of measuring outcome-based trade openness taking into account two additional dimensions of countries' integration in world trade: the quality and the variety of the exported basket. Indeed, according to the existing literature both these factors are likely to affect positively growth, which call for considering them when measuring countries' trade openness in view of examining the relationship between trade and growth.

On the one hand, endogenous growth theory has provided a framework for efficiency gains and a positive growth effect of trade through innovation incentives, technology diffusion and knowledge dissemination (Young, 1991; Grossman and Helpman, 1991). In these types of models, the introduction of new varieties through imports leads to static gains from trade taking the form of increased productivity and domestic production growth, by making imported intermediate inputs cheaper and by relaxing technological constraints faced by producers through the access to new imported input varieties. The consumption of increased variety also leads to welfare gains due to the love of variety. Dynamic gains arise when the resulting growth fosters the creation of new domestic varieties that contribute further to economic growth. There is increasing evidence at the firm level on this regard; for example, Bigsten et al. (2016) recently found that inputs tariff liberalization was associated with higher firm-level productivity in Ethiopia. Bas and Strauss-Kahn (2014) showed that French firms importing more varieties of intermediate inputs increased their productivity by $2.5 \%$ and exported more varieties. Goldber et al. (2010) showed that lower input tariffs accounted on average for $31 \%$ of the new products introduced by domestic firms in India, thanks to increased firm access to new input varieties. However, there is no consensus on the magnitude of welfare gains, as these will depend on the share of new imported varieties in total consumption (Arkolakis et al. 2008). 
Inspired from theoretical developments on innovations incentives and knowledge spillovers, Hausmann et al. (2007) proposed an analytical framework linking the type of goods (as defined in terms of productivity level) a country specializes in to its rate of economic growth. In order to test empirically for this relationship, they defined an index aiming at capturing the productivity level (or the quality) of the basket of goods exported by each country. Using various panel data estimators during the period $1962-2000$, their growth regression showed that countries exporting goods with higher productivity levels (or higher quality goods) have higher growth performances. These results suggest that what countries export matters as regards the growth effect of trade. Hence, our measurement of trade openness should consider this quality dimension as a complement to the trade ratio (or the dependency) dimension.

On the other hand, monopolistic competition trade models with heterogeneous firms and endogenous productivity provide theoretical support for a positive impact of trade openness on growth. Indeed, the theory predicts a productivity improvement in the country due to a reallocation effect after the exit of less efficient firms following trade liberalization -or a reduction in transport costs for example- (Melitz, 2003). Furthermore, a higher share of the most productive firms will start exporting, which translates into an increase in the variety of exports. As exporters are more productive on average than domestic firms, an increase in exports variety can be associated to rising country productivity. Based on this literature, Feenstra and Kee (2008) developed a model allowing to link, across countries and over time, relative export variety to total factor productivity using a Gross Domestic Product (GDP) function. They tested this relationship on the basis of exports to the US for a panel of 48 countries over the period 1980-2000 using three stage least squares regressions. Their empirical results indicated that there is a positive and significant relationship between export variety and average productivity. Furthermore, computing the gains from trade in the monopolistic competition model of Melitz (2003), Feenstra (2010) shows that countries with a greater export over GDP ratio will experience higher gains in terms of GDP per capita growth, from export variety. Once again, these results suggest that, in addition to the trade dependency ratio, the structure of countries' exports matters regarding the growth effect. Hence, our measurement of trade openness should also consider this variety dimension.

Our empirical application draws on the Barro and Lee (1994)'s model, extended to account for our set of three indicators of trade openness: trade dependency ratio, quality index and variety index. Barro and Lee (1994) study empirical determinants of growth. They are in line with the endogenous growth theory. Unlike the usual neoclassical growth model for a closed economy (Solow, 1956), endogenous growth models take into account the sources of technological progress (human capital, role of government for instance). Thus, we include some proxies for trade openness in our empirical model as potential sources of technological change.

One main limitation of our trade openness indicators lies in their endogeneity in growth regressions, which requires specific estimation techniques. This constitutes the second shortcoming in existing empirical evidence pointed out by Rodriguez and Rodrik (2001). As argued by Lee et al. (2004), all measures of openness are closely linked to the economic growth rate. Hence, it is likely that all measures of openness are jointly endogenous with economic growth, which may cause biases in estimation resulting from simultaneous or reverse causation. Various methods have been used to remedy this problem and there is still a debate among scientists about which method is the most appropriate (Dollar and Kraay, 2004; and Lee et al., 2004, among others). 
In this paper, we perform estimations on 4-year averaged data over the period 1988-2014 for an unbalanced panel of 169 countries. We use a Generalized Method of Moments (GMM) estimation approach developed for dynamic panel data models in order to deal with the potential endogeneity bias due to omitted variables, simultaneity and measurement error.

Our results confirm that countries more open to trade and exporting higher quality products experience higher growth. More importantly, we point out an interesting pattern of non linearity in the growth effect of the trade ratio: the higher the quality of the export basket of the country, the greater the positive impact of trade on economic growth. In addition, there is a minimum level of export quality under which trade can be detrimental to growth. This non-linear pattern in the trade to growth relationship is found for the whole sample and for various subsamples of developing countries. It has particularly important implications for developing countries since as they often exhibit low quality export baskets, they are therefore more likely to experience a negative trade impact on growth.

From our estimation results we also confirm a non linear relationship between the export variety (or extensive margin), the export ratio and growth. Trade openess has often a positive impact on growth per se; but this relationship seems to exist starting a certain degree of the extensive margin of exports. As most developing countries are above this threshold, a higher exposure of the economy to exports should lead to higher growth. Furthermore, export diversification through the extensive margin appears as complementary strategy to increase the contribution of trade to economic growth.

The remainder of the article is organized as follows. In the next section, we present the specification of performed growth regressions and the retained econometric methodology. Section 3 reports and discusses empirical results, while section 4 concludes.

\section{2 - SPECIFICATION OF GROWTH REGRESSIONS AND ECONOMETRIC METHODOLOGY}

Inspired from Barro and Lee (1994)'s approach we retain the following specification:

$\ln \left(\frac{G D P}{p o p}\right)_{i, t}=\alpha \ln \left(\frac{G D P}{p o p}\right)_{i, t-1}+\beta_{1}$ education $_{i, t}+\beta_{2} \ln \left(\right.$ life $_{i, t}+\beta_{3}\left(\frac{I}{G D P}\right)_{i, t}+\beta_{4}\left(\frac{X}{G D P}\right)_{i, t}+\mu_{i}+\gamma_{t}+v_{i, t}$

where the dependent variable is the logarithm of GDP per capita of country $i$ for period $t$, with GDP corresponding to Gross Domestic Product and pop to the total population. Explanatory variables are the following. First, the initial level of GDP per capita is included to test for the impact of initial conditions. Countries' endowments in production factors are controlled for using the average level of human capital investment, which is approximated through the level of education (education) and the life expectancy at birth (life); and the physical investment as 
measured by the investment over GDP ratio $\left(\frac{I}{G D P}\right)^{1}$. The effects of education, life expectancy and investment ratio are likely to be positive. Finally, in order to test for the impact of trade on income per capita, we choose as a measure of trade openness the export ratio $\left(\frac{X}{G D P}\right.$, that is exports over GDP), an export quality index (Quality), an export variety index (Variety) and the combined effect of the export ratio with each of these indices. We decided to choose the export ratio instead of the usual trade ratio $\left(\frac{X+M}{G D P}\right.$, that is the sum of exports and imports over GDP) in order to keep consistency with the quality and the variety indices which are concerned with traderelated growth mechanisms arising from the export side.

Thus, our two alternative specifications are:

- an extended specification including the export quality index (Quality) and its cross impact with the export ratio:

$$
\begin{aligned}
& \ln \left(\frac{G D P}{p o p}\right)_{i, t}=\alpha \ln \left(\frac{G D P}{p o p}\right)_{i, t-1}+\beta_{1} \text { education }_{i, t}+\beta_{2} \ln (\text { life })_{i, t}+\beta_{3}\left(\frac{I}{G D P}\right)_{i, t}+\beta_{4}\left(\frac{X}{G D P}\right)_{i, t} \\
& +\beta_{5} \ln \left(\text { Quality }_{i, t}+\beta_{6}\left(\frac{X}{G D P}\right)_{i, t} * \ln (\text { Quality })_{i, t}+\mu_{i}+\gamma_{t}+v_{i, t}\right.
\end{aligned}
$$

- an extended specification with the alternative export variety index (Variety) and its cross impact with the export ratio:

$$
\begin{aligned}
& \ln \left(\frac{G D P}{\text { pop }}\right)_{i, t}=\alpha \ln \left(\frac{G D P}{p o p}\right)_{i, t-1}+\beta_{1} \text { education }_{i, t}+\beta_{2} \ln (\text { Life })_{i, t}+\beta_{3} \ln \left(\frac{I}{G D P}\right)_{i, t}+\beta_{4}\left(\frac{X}{G D P}\right)_{i, t} \\
& +\beta_{5}\left(\text { Variety }_{i, t}+\beta_{6}\left(\frac{X}{G D P}\right)_{i, t} *\left(\text { Variety }_{i, t}+\mu_{i}+\gamma_{t}+v_{i, t}\right.\right.
\end{aligned}
$$

The model includes time-specific effects $\left(\gamma_{t}\right)$ accounting for period-specific effects such as productivity changes that are common to all countries or the global effect of US dollar appreciation, country-specific fixed-effects ( $\mu_{i}$ ) that take into account country-specific features that are constant in time, such as geography, and an error term ( $v_{i, t}$ ).The high collinearity between the variety and the quality index (correlation reaching $50 \%$ ) forces us to estimate the non-linear effects conditional on the export ratio in two separate regressions (2) and (3).

Our empirical estimation is run on an unbalanced panel of 169 countries for the period 1988-2014 using 4-year averaged data (except for initial GDP per capita that takes the first observation within each period). As most explanatory variables are likely to be jointly endogenous with economic growth while important variables for instance the country-specific effects are not observable and omitted in the estimation, estimating this model by Ordinary Least Squares (OLS) or Within group estimations would potentially lead to biased results. Thus, we use the System-GMM estimator developed for dynamic panel data models (Arellano and Bover, 1995; Blundell and

\footnotetext{
${ }^{1}$ Due to the lack of available data, general government final consumption expenditure ratio, black market premium and revolution variables used by Barro and Lee (1994) are not introduced here.
} 
Bond, 1998). The main advantage of this estimator is that it does not require any external instrument to deal with endogeneity.

Within the GMM approach, one may choose the first-differenced estimator, which considers regression equations in first-differences instrumented by lagged levels of explanatory variables. Taking first-differences eliminates country-specific fixed-effects, thus solving the problem of the potential omission of time invariant country specific factors that may influence growth. Nevertheless, the first-differenced GMM estimator (Arellano and Bond, 1991) is not suitable when time series are persistent and the number of time series observations is small, like in the case of empirical growth models where data has to be averaged in order to avoid modelling cyclical dynamics (Bond et al., 2001). Under these conditions, lagged levels of explanatory variables tend to be weak instruments for subsequent first-differences, thus producing biased estimates. Therefore, Arellano and Bover (1995) and Blundell and Bond (1998) suggest to retain the System-GMM approach, which combines - into one system - regression equations in first-differences and in levels, where instruments used for level equations are lagged first-differences of the series. Bond et al. (2001) argue that the assumption whereby deviations of $y_{i, 1}$ from long-run steady-state values do not depend on unobserved fixed-effects (even if the latest can affect the level of steady-state outputs) may be valid in growth model frameworks, thus allowing us to estimate the model with a System-GMM. ${ }^{2}$

Thus, System-GMM estimator implies running a GMM procedure on the following system of equations:

$y_{i, t}-y_{i, t-1}=\alpha\left(y_{i, t-1}-y_{i, t-2}\right)+\beta^{\prime}\left(X_{i, t}-X_{i, t-1}\right)+\left(\tau_{t}-\tau_{t-1}\right)+\left(v_{i, t}-v_{i, t-1}\right)$

and

$$
y_{i, t}=\alpha y_{i, t-1}+\beta^{\prime} X_{i, t}+\tau_{t}+\eta_{i}+v_{i, t}
$$

In order to test for the appropriateness of our retained instruments, we consider two specification tests. The first one is the Hansen J-test of over-identification for which the null hypothesis is that the chosen instruments are valid. The second one examines whether the idiosyncratic disturbance term $v_{i, t}$ is serially correlated. The test is performed on the first-differenced error term (that is, the residual of equation (4)) and the null hypothesis is that the latter is second-order uncorrelated. In both cases, failure to reject the null hypothesis gives support to our retained specification.

Even though the System-GMM estimator can be very appealing as it offers solutions to deal with numerous estimation problems very common in growth regressions (i.e. a short panel, dynamic dependent variables, fixed effects and a lack of good external instruments) it also suffers from several caveats that need to be discussed and addressed; in particular the issue of instruments proliferation (Roodman, 2009). Using by default the largest available number of internal instruments to control for endogeneity and dynamic panel bias, System-GMM can lead to severe biased estimates of both the coefficients of interest and the standard errors, while apparently passing the standard Hansen J-test. As mentioned in Roodman (2009), there are two ways to address this issue: limiting

\footnotetext{
2 Technical developments are reported in Annex D.
} 
the number of lags used instead of using all available lags as instruments, and "collapsing" the instrument matrix. We applied both techniques in our specifications to limit biases introduced by instrument proliferation.

\section{3 - DATA AND RESULTS}

a. Data

To reduce the impact of business cycles, we use a total of 4-year averaged data between 1988 and 2014 for an unbalanced panel of 169 countries (Annex A provides the full list of countries in the sample). Most required data are extracted from the World Bank World Development Indicators (WDI) database, as it is the case for the following variables. The dependent variable is computed using the GDP per capita based on purchasing power parity (expressed in constant 2011 US dollars). The investment ratio is proxied through the gross fixed capital formation in percentage of GDP; the life expectancy at birth is the number of years one is expected to stay alive when birthing; and the education level is measured as the gross secondary school enrolment ratio. The export ratio is computed using GDP as well as values of exports of goods and services in current US dollars.

The export quality index is computed according to the Hausmann et al. (2007)'s approach and the variety indicator according to Feenstra and Kee (2008) and Feenstra (2010). They are both computed based on export values in current US dollars constructed using mirror flows extracted from the COMTRADE database at the HS-6 level data. Further details on the definition and computation of these indicators can be found in annex E. Table 1 summarizes some basic descriptive statistics for all variables used in growth regressions.

\section{Please Insert Table 1 : Descriptive statistics for variables used in the model}

Descriptive statistics reveal heterogeneity on our three variables of interest: the export ratio, export quality and export variety, as the standard deviation is quite high compared to the mean. Interestingly, Figures 1 and 2 reveal that even though each of these variables seems to be positively correlated with GDP per capita, there seems to be a certain degree of complementarity between them vis-a-vis their relationship to income. For example, for the last quintile of the export ratio, the quality of exports has to go beyond a certain threshold for its relationship with GDP per capita to be positive. This is also the case for the export variety (or extensive margin) conditional on the export ratio. These non-linearities are the starting point of the empirical strategy of this paper, where likely complementarities are tested using interactive terms (equations 2 and 3 ).

Please insert Figure 1: Non linearities between the export ratio, export quality and GDP growth (1988-2014)

Please insert Figure 2: Non linearities between the export ratio, export variety and GDP growth (1988-2014)

\section{b. Empirical results}

In this section we examine whether trade openness can be considered as a main determinant of growth. Results of the first regression (1) are reported as a benchmark in Table 2 since they refer to the specification including the export ratio as the single measure of trade openness. The quality and the variety index as additional measures of 
trade openness are presented in columns (2) and (4) respectively. Results of the regressions including in addition the cross effect of the export ratio with the quality and with the variety index are reported in columns (3) and (5) respectively.

As far as the first specification is concerned, Table 2 indicates that when trade openness is measured by the export ratio only, it appears as a significant determinant of growth. Interestingly, column (2) shows that when trade openness is measured by both the export ratio and the export quality index, both have a positive and significant impact on GDP per capita growth. This result confirms Hausmann et al. (2007)'s result that a higher quality of exports enhances growth.

Finally, column (3) reveals an interesting non-linear pattern between trade openness and growth once the export ratio is crossed with the quality index, as both this variable and the export ratio appear statistically significant. Our estimation results suggest that trade may have a negative impact on growth when countries have specialized in low quality products; trade clearly enhances growth once countries have specialized in high quality products and their export basket exhibits a minimum required level of quality. The corollary is also true, as the higher the quality of the export basket, the greater the impact of the export ratio on growth. It is worth noting that these results remain unchanged when adding the variety index in the same regression, suggesting that the export quality has a distinctive impact from the export variety on economic growth ${ }^{3}$. More specifically, Table 2 indicates that, all other things being unchanged, one percentage point increase in the export ratio would raise the 4-years average GDP per capita by $(-0.022+0.003 * \operatorname{Ln}$ Quality). Hence, a minimum level of quality of the export basket is required (1 530 USD) for the impact of the export ratio starts to be positive. As indicated by Table 1, this threshold is much lower than the average of the export quality index over the whole sample (13 607 USD) suggesting that trade is likely to enhance growth in most countries.

Once we exclude major oil exporting countries from the sample (column $\left(3 \_\right.$o) $),{ }^{4}$ results remain similar to those of specification (3), suggesting no specific behaviour for these countries. It is interesting to note that the minimum level of quality of the export basket required for a positive impact of the export ratio on the GDP per capita growth remains quite similar (1 808 USD).

Taking the last period of our sample (2010-2014), countries below this threshold are mainly African least developed countries (see Annex B). This suggests that increasing the dependency of their economy to trade without ensuring an improvement of the quality of their exports may have negative consequences in terms of growth. Thus, a strategy to enhance value-added to exports seems crucial for them.

Turning now to the variety dimension, specification (4)'s results show that when trade openness is measured by both the export ratio and the export variety index, both have a positive and significant impact on GDP per capita.

\footnotetext{
${ }^{3}$ The high collinearity between the variety and the quality index forces us to estimate the two non-linear effects conditional on the export ratio in two separate regressions. However, results remain unchanged when controlling for the level of export variety in the estimation of the non-linear relationship between export quality and the export ratio (and vice-versa for the level of export quality in the alternative specification). Results are available upon request.

${ }^{4}$ A country is considered to be a major oil exporting country if on average, over the $1988-2014$ period, the value of its oil exports account for more than $2 / 3$ of the value of its total exports (these countries represent $11 \%$ of the whole sample). One must underline that results are robust to changing this oil over total exports threshold to $50 \%$.
} 
This result is in line with Feenstra and Kee (2008) and Feenstra (2010) which suggest that a higher variety of exports contributes to enhance growth.

However, when we add the cross effect of the export ratio and the variety index only the latter appears slightly statistically significant (column 5). When major oil exporting countries are excluded from the sample (specification (5_o)), one recovers the non-linear impact of trade on growth: the cross effect of the export ratio and the variety index is positive and statistically significant; and the effect of the export ratio is negative. . Results also remain unchanged when adding the quality index in the same regression, suggesting that the export variety has a distinctive impact from the export quality (results available upon request). Results indicate that, all other things being unchanged, one percentage point increase in the export ratio would raise the 4-years average GDP per capita by $\left(-0.002+0.006^{*}\right.$ Variety $)$. Hence, a minimum level of variety of the export basket is required $(0.33)$ for the impact of the export ratio starts to be positive. As indicated by Table 1, this threshold is lower than the average of the export variety index over the whole sample (0.55) and its standard deviation; suggesting that trade is likely to enhance growth for almost all countries. Countries below this threshold in the last period are mainly island states (see Annex C); which share specific structural characteristics explaining the low level of export variety.

Regarding control variables, Table 2 shows that initial GDP per capita exhibit an expected positive and lower than unity statistically significant coefficient. Among the main growth determinants considered by Barro and Lee (1994), the investment ratio has an expected positive and significant impact in most of the specifications. In terms of human capital, surprisingly nor the secondary enrolment ratio nor the life expectancy at birth have a significant impact on GDP per capita growth when we add the variety. Finally, it should be noted that for all estimations, Hansen and AR(2) specification tests give support to our retained GMM-System estimator. The lagged variables that are chosen appear as good instruments in the present context.

To check the robustness of our results we performed the same regressions on various sub-samples covering different groups of developing countries defined according to the 2016 World Bank income classification (Table 3). We work first with the sub-sample of Developing Countries (DC); and within it, with Low Income Countries (LIC) and Lower Middle Income Countries (LMIC). As done previously, we also consider the corresponding subsamples excluding the major oil exporting countries.

\section{Please Insert Table 2: Growth regressions results using System-GMM estimator for the period 1988-2014}

For the estimations with the quality index crossed with the export ratio run over the sample of developing countries, results obtained are similar to previous one. Indeed, we recover the non-linear pattern between trade openness and growth. As for estimations with the variety index crossed with the export ratio, results are robust for LIC\&LMIC with and without oil and for DC without oil; estimates confirm the non-linear relationship between the export ratio, export variety and growth. Indeed, specifications $\left(5^{\prime \prime}\right),\left(5^{\prime}{ }_{-}\right)$and $\left(5^{\prime \prime}, \mathrm{o}\right)$ show that the cross effect with the export ratio is positive and significant. These results suggest that trade dependency and the extensive margin of exports contribute jointly to increase GDP per capita. 
Please Insert Table 3: Robustness analysis using various sub-samples of developing countries 


\section{4 - CONCLUSION}

This paper investigates the relationship between trade openness and economic growth. Starting from the idea that trade openness cannot be fully characterized through the trade ratio only, we propose to account for two additional dimensions of countries' trade integration: export quality and export variety. Then, following Barro and Lee (1994), standard growth regressions are performed where, among the explanatory variables, the commonly used trade ratio (here the export ratio) is complemented by the Hausmann et al. (2007)'s export quality index or the Feenstra and Kee (2008)'s export variety index. Our empirical application is based on 4-year averaged data over the period 1988-2014 for an unbalanced panel of 169 countries. As most explanatory variables are likely to be jointly endogenous with economic growth, we use the System-GMM estimator developed for dynamic panel data models.

Our empirical results are in line with New International Economics insights that regarding the relationship between trade openness and growth, in addition to the trade ratio, the quality and the variety of the export basket matter. We point out an interesting non-linear pattern between trade openness and growth when export quality is taken into account: trade may have a negative impact on growth when countries have specialized in low quality products; trade clearly enhances growth once countries have specialized in high quality products and their export basket exhibits a minimum required level of quality. Therefore, there is some pattern of complementarity between trade dependency and trade in quality so that the higher the quality of the export basket, the greater the impact of the export ratio on growth.

Estimation results also suggest a non-linear relationship between trade and growth when the variety of exports (or extensive margin) is taken into account. The impact of an increase in the export variety on growth seems positive for almost all countries, except for those with a low level of exported variety (mainly Island states). For most developing countries, we find some pattern of complementarity between trade dependency and export variety: the export ratio has a positive impact on GDP per capita and the higher the variety of the export basket, the higher the impact of the trade ratio. It is interesting to note that the cross effect of the export ratio and the export variety index clearly relates to changes at the intensive and extensive margins (even if our export ratio cannot be properly disentangled between the two margins, the export variety index is a proxy for the extensive margin). Hence, further investigations at the macroeconomic level are required to clarify the role of trade dependency and each trade margin as regards the relationship between trade and growth.

From an economic policy perspective, these results suggest that investment in quality infrastructure and in productive capacity to move developing countries 'production up the quality chain could be decisive to enhance growth. Also, they show that increasing the extensive margin of exports by the introduction of new products to the export bundle, through carefully designed innovation or export promotion initiatives for example, can have important implications for development. As Aid for Trade, and in particular aid for building productive capacity, intends to focus on these matters, further evidence on its link with the quality and the variety of exports seems to be necessary. 


\section{REFERENCES}

Arellano, M. and S. Bond (1991), 'Some tests of specification for panel data: Montecarlo evidence and an application to employment equations', Review of Economic Studies, 58, 2, 277-297.

Arellano, M. and O. Bover (1995), 'Another look at the instrumental-variable estimation of error-components models', Journal of Econometrics, 68, 1, 29-52.

Arkolakis, C., S. Demidova, P. J. Klenow and A? Rodriguez-Clare (2008), 'Endogenous Variety and the Gains from Trade', American Economic Review, 98, 2, 444-50.

Bas, M and V Strauss-Kahn (2014), "Does importing more inputs raise exports? Firm-level evidence from France”, Review of World Economics, 150, 2, 241-475.

Barro R. J. and J-W. Lee (1994), 'Sources of economic growth', Carnegie-Rochester Conference Series on Public Policy, 40, 1-46.

Bigsten A., M. Gebreeyesus and M. Soderbom (2016), 'Tariffs and Firm Performance in Ethiopia', The Journal of Development Studies, in press.

Blundell, R. and S. Bond (1998), 'Initial conditions and moment restrictions in dynamic panel data models', Journal of Econometrics, 87, 1, 115-143.

Blundell, R. and S. Bond (1998), 'GMM estimation with persistent panel data: an application to production functions', The Institute for Fiscal Studies (IFS) Working Paper Series No. W99/4.

Bond, R., A. Hoeffler and J. Temple (2001), 'GMM estimation of empirical growth models', CEPR Discussion Paper Series, No. 3048.

Chang R., L. Kaltani and N.V. Loayza (2009), 'Openness can be good for growth: the role of policy complementarities', Journal of Development Economics, 90, 33-49.

De Melo, J. and J. M. Grether (2000), 'Commerce International : Théories et Applications', De Boeck University.

Dollar, D. and A. Kraay (2004), 'Trade, Growth, and Poverty', The Economic Journal, 114, February, 22-49.

Edwards, S. (1998), 'Openness, productivity and growth: what do we really know?' The Economic Journal, 108, March, 383-98.

Feenstra, R. C. (1994), 'New product varieties and the measurement of international prices', American Economic Review, 84, 1, 157-177.

Feenstra, R. C and H. L. Kee (2008), 'Export variety and country productivity: Estimating the monopolistic competition model with endogenous productivity', Journal of International Economics, 74, 500-518.

Feenstra, R. C. (2010), 'Measuring the gains from trade under monopolistic competition', Canadian Journal of Economics, 43, 1, 1-28.

Frankel, J. and D. Romer (1999), 'Does Trade Cause Growth?’, American Economic Review, 89, 3, 379-99.

Frankel, J. and A. Rose (2002), 'An Estimate of the Effect of Common Currencies on Trade and Income', The Quarterly Journal of Economics, 117, 2, 437-66.

Freund, C. and B. Bolaky (2008), 'Trade, regulations, and income', Journal of development economics, 87, 309321.

Goldberg P., A. Khandelwal, N. Pavcnik and P. Topalova (2010), 'Imported Intermediate Inputs and Domestic Product Growth: Evidence from India‘, The Quaterly Journal of Economics, 124, 4, 1727-1767.

Grossman, G. and E. Helpman (1991), 'Innovation and growth in the World economy', Cambridge, MA: MIT. 
Harrison, A. (1996), 'Openness and growth: A time-series, cross-country analysis for developing countries', Journal of Development Economics, 48, 419-447.

Hausmann, R., J. Hwang, and D. Rodrik (2007), 'What you export matters', Journal of Economic Growth, 12, 125 .

Hummels, D. and P.J. Klenow (2005), 'The variety and quality of a nation's exports', The American Economic Review, 95, 3, 704-723.

Irwin, D. and M. Tervio (2002), 'Does Trade Raise Income? Evidence from the Twentieth Century', Journal of International Economics, 58, 1, 1-18.

Lee, H.Y., L.A. Ricci and R. Rigobon (2004), 'Once Again, Is Openness Good for Growth?’ NBER Working Paper 10749 (Cambridge, MA: NBER).

Lederman, D. and W. F. Maloney (2008), 'In search of the missing resource curse', Policy Research paper 4766, World Bank, Washington.

Melitz, J.M. (2003), 'The impact of trade on intra-industry reallocations and aggregate industry productivity', Econometrica, 71, 6, 1695-1725.

Pritchett, L. (1996), 'Measuring Outward Orientation in LDCs: Can It Be Done?', Journal of Development Economics, 49, 307-35.

Rodriguez, F. and D. Rodrik (2001), 'Trade Policy and Economic Growth: A Skeptic's Guide to the Cross-National Evidence'. In NBER (ed.), NBER Macroeconomics Annual 2000, NBER Chapters, (Cambridge: National Bureau of Economic Research), 261-338.

Roodman, D. (2009), 'A Note on the Theme of Too Many Instruments', Oxford Bulletin of Economics and Statistics, 71, 1, 135-158.

Sachs, J. D. and A. M. Warner (1995), 'Natural Resource Abundance and Economic Growth', NBER Working Papers 5398 (Cambridge: NBER)..

Solow, R.M. (1956), 'A contribution to the theory of economic growth', Quarterly Journal of Economics, 70, 65 94.

Squalli, J. and K. Wilson (2011), ‘A new measure of trade openness', The World Economy, 34, 10, 1745-1770.

Wacziarg, R. and K. H. Welch (2003), ‘Trade Liberalization and Growth: New Evidence'. NBER Working Paper 10152 (Cambridge: NBER).

Windmeijer, F. (2005), 'A finite sample correction for the variance of linear efficient two-step GMM estimators', Journal of Econometrics, 126, 25-51.

World Development Report (1987), Oxford University Press, 301 pages.

Yanikkaya, H. (2003), 'Trade openness and economic growth: A cross-country empirical investigation', Journal of Development Economics, 72, 57-89.

Young, A. (1991), 'Learning by doing and the dynamic effects of international trade', Quarterly Journal of Economics, 106, 369-405. 
Table 1: Descriptive statistics for variables used in the model

\begin{tabular}{l|lllll}
\hline Variables & Obs & Mean & Std. Dev. & Min & Max \\
\hline GDP per capita PPP (constant 2011 USD) & 1291 & 14447.60 & 17067.44 & 369.01 & 133666.88 \\
Education (\%) & 1151 & 71.95 & 30.12 & 5.34 & 157.36 \\
Life expectancy (years) & 1401 & 67.92 & 9.56 & 28.22 & 83.32 \\
Investment / GDP (\%) & 1225 & 22.57 & 9.32 & 4.27 & 186.22 \\
Exports / GDP (\%) & 1289 & 37.86 & 22.68 & 0.18 & 219.42 \\
Export quality ( USD) & 1402 & 13607.27 & 5561.31 & 734.77 & 38658.80 \\
Export variety (\%) & 1402 & 0.55 & 0.30 & 0.00 & 1.00 \\
\hline
\end{tabular}

Source: Authors' calculations 
Table 2: Growth regressions results using System-GMM estimator for the period 1988-2014

\begin{tabular}{|c|c|c|c|c|c|c|c|}
\hline \multirow[b]{2}{*}{ Ln (GDP/pop) final } & \multicolumn{4}{|c|}{ Total sample } & \multirow[b]{2}{*}{$(5)$} & \multicolumn{2}{|c|}{ Without oil } \\
\hline & (1) & (2) & (3) & $(4)$ & & $\left(3 \_0\right)$ & $(5 \circ)$ \\
\hline Ln (GDP/pop) init. & $\begin{array}{l}0.889 * * * \\
(0.031)\end{array}$ & $\begin{array}{l}0.858 * * * \\
(0.025)\end{array}$ & $\begin{array}{l}0.863 * * * \\
(0.022)\end{array}$ & $\begin{array}{l}0.935 * * * \\
(0.038)\end{array}$ & $\begin{array}{l}0.942 * * * \\
(0.030)\end{array}$ & $\begin{array}{l}0.873 * * * \\
(0.024)\end{array}$ & $\begin{array}{l}0.930 * * * \\
(0.031)\end{array}$ \\
\hline Education & $\begin{array}{l}0.003 * * \\
(0.001)\end{array}$ & $\begin{array}{l}0.002 * * \\
(0.001)\end{array}$ & $\begin{array}{l}0.002 * * * \\
(0.001)\end{array}$ & $\begin{array}{l}-0.001 \\
(0.001)\end{array}$ & $\begin{array}{l}-0.001 \\
(0.001)\end{array}$ & $\begin{array}{l}0.002 * * * \\
(0.001)\end{array}$ & $\begin{array}{l}0.000 \\
(0.001)\end{array}$ \\
\hline I/GDP & $\begin{array}{l}0.004 * * * \\
(0.002)\end{array}$ & $\begin{array}{l}0.006 * * * \\
(0.001)\end{array}$ & $\begin{array}{l}0.006^{* * *} \\
(0.001)\end{array}$ & $\begin{array}{l}0.005^{* * *} \\
(0.001)\end{array}$ & $\begin{array}{l}0.007 * * * \\
(0.002)\end{array}$ & $\begin{array}{l}0.004 * * * \\
(0.001)\end{array}$ & $\begin{array}{l}0.003 \\
(0.002)\end{array}$ \\
\hline Ln (life expec.) & $\begin{array}{l}0.190 \\
(0.158)\end{array}$ & $\begin{array}{l}0.273^{*} \\
(0.143)\end{array}$ & $\begin{array}{l}0.208^{*} \\
(0.115)\end{array}$ & $\begin{array}{l}0.145 \\
(0.235)\end{array}$ & $\begin{array}{l}-0.102 \\
(0.209)\end{array}$ & $\begin{array}{l}0.214 * * \\
(0.100)\end{array}$ & $\begin{array}{l}-0.009 \\
(0.184)\end{array}$ \\
\hline X/GDP & $\begin{array}{l}0.003 * * \\
(0.001)\end{array}$ & $\begin{array}{l}0.002 * * * \\
(0.001)\end{array}$ & $\begin{array}{l}-0.022 * * \\
(0.011)\end{array}$ & $\begin{array}{l}0.002 * * \\
(0.001)\end{array}$ & $\begin{array}{l}-0.002 \\
(0.002)\end{array}$ & $\begin{array}{l}-0.015+ \\
(0.010)\end{array}$ & $\begin{array}{l}-0.005^{* *} \\
(0.002)\end{array}$ \\
\hline Ln (quality) & & $\begin{array}{l}0.156 * * * \\
(0.036)\end{array}$ & $\begin{array}{l}0.065 \\
(0.053)\end{array}$ & & & $\begin{array}{l}0.030 \\
(0.056)\end{array}$ & \\
\hline $\mathrm{X} / \mathrm{GDP} *$ Ln (quality) & & & $\begin{array}{l}0.003 * * \\
(0.001)\end{array}$ & & & $\begin{array}{l}0.002 * \\
(0.001)\end{array}$ & \\
\hline Variety & & & & $\begin{array}{l}0.211^{*} \\
(0.127)\end{array}$ & $\begin{array}{l}0.015 \\
(0.177)\end{array}$ & & $\begin{array}{l}-0.118 \\
(0.162)\end{array}$ \\
\hline $\mathrm{X} / \mathrm{GDP} *$ variety & & & & & $\begin{array}{l}0.006+ \\
(0.004)\end{array}$ & & $\begin{array}{l}0.008 * * * \\
(0.003)\end{array}$ \\
\hline Constant & $\begin{array}{l}-0.168 \\
(0.596)\end{array}$ & $\begin{array}{l}-1.690 * * * \\
(0.578)\end{array}$ & $\begin{array}{l}-0.603 \\
(0.612)\end{array}$ & $\begin{array}{l}-0.264 \\
(0.820)\end{array}$ & $\begin{array}{l}0.783 \\
(0.834)\end{array}$ & $\begin{array}{l}-0.361 \\
(0.580)\end{array}$ & $\begin{array}{l}0.622 \\
(0.682)\end{array}$ \\
\hline Observations & 1029 & 810 & 810 & 810 & 810 & 719 & 719 \\
\hline Number of panelid & 206 & 169 & 169 & 169 & 169 & 146 & 146 \\
\hline $\mathrm{AR}(2)$ test $\mathrm{p}$-value & 0.459 & 0.306 & 0.393 & 0.279 & 0.484 & 0.521 & 0.792 \\
\hline Hansen test $p$-value & 0.165 & 0.269 & 0.239 & 0.680 & 0.752 & 0.479 & 0.745 \\
\hline
\end{tabular}

Standard errors in parentheses. ${ }^{* * *} \mathrm{p}<0.01, * * \mathrm{p}<0.05, * \mathrm{p}<0.1,+\mathrm{p}<0.15$

Estimation method: GMM system (Arellando and Bover, 1995; Blundell and Bond, 1998) with Windmeijer (2005) correction for small sample biais. Exogenous variables used as instruments are year dummies (Roodman, 2009) for the system.

Source: Authors' calculations. 
Table 3: Robustness analysis using various sub-samples of developing countries

\begin{tabular}{|c|c|c|c|c|c|c|c|c|}
\hline \multirow[b]{2}{*}{ Ln (GDP per capita final) } & \multicolumn{2}{|c|}{$\mathrm{DC}$} & \multicolumn{2}{|c|}{ LIC\&LMIC } & \multicolumn{2}{|c|}{ DC without oil } & \multicolumn{2}{|c|}{ LIC\&LMIC without oil } \\
\hline & $\left(3^{\prime}\right)$ & $\left(5^{\prime}\right)$ & $\left(3{ }^{\prime \prime}\right)$ & $\left(5^{\prime \prime}\right)$ & $\left(3^{\prime} \_\right.$o) & $\left(5^{\prime} \_0\right)$ & $(3$ '”o) & $\left(5^{\prime \prime} \_\right)$ \\
\hline Ln (GDP per capita init.) & $\begin{array}{l}0.886 * * * \\
(0.022)\end{array}$ & $\begin{array}{l}1.001 * * * \\
(0.063)\end{array}$ & $\begin{array}{l}0.888 * * * \\
(0.027)\end{array}$ & $\begin{array}{l}1.005 * * * \\
(0.067)\end{array}$ & $\begin{array}{l}0.896 * * * \\
(0.024)\end{array}$ & $\begin{array}{l}0.962 * * * \\
(0.061)\end{array}$ & $\begin{array}{l}0.877 * * * \\
(0.032)\end{array}$ & $\begin{array}{l}0.969 * * * \\
(0.075)\end{array}$ \\
\hline Education & $\begin{array}{l}0.002 * * * \\
(0.001)\end{array}$ & $\begin{array}{l}-0.002 \\
(0.002)\end{array}$ & $\begin{array}{l}0.001 * * \\
(0.001)\end{array}$ & $\begin{array}{l}-0.002 \\
(0.002)\end{array}$ & $\begin{array}{l}0.001 * * \\
(0.001)\end{array}$ & $\begin{array}{l}-0.002 \\
(0.003)\end{array}$ & $\begin{array}{l}0.002 * * \\
(0.001)\end{array}$ & $\begin{array}{l}-0.000 \\
(0.003)\end{array}$ \\
\hline I/GDP & $\begin{array}{l}0.005^{* * *} * \\
(0.001)\end{array}$ & $\begin{array}{l}0.003 \\
(0.004)\end{array}$ & $\begin{array}{l}0.004 * * * \\
(0.001)\end{array}$ & $\begin{array}{l}0.001 \\
(0.003)\end{array}$ & $\begin{array}{l}0.004 * * * \\
(0.001)\end{array}$ & $\begin{array}{l}0.001 \\
(0.005)\end{array}$ & $\begin{array}{l}0.004 * * * \\
(0.001)\end{array}$ & $\begin{array}{l}0.002 \\
(0.006)\end{array}$ \\
\hline Ln (life expec.) & $\begin{array}{l}0.118 \\
(0.083)\end{array}$ & $\begin{array}{l}0.078 \\
(0.195)\end{array}$ & $\begin{array}{l}0.118 \\
(0.104)\end{array}$ & $\begin{array}{l}0.144 \\
(0.173)\end{array}$ & $\begin{array}{l}0.103 \\
(0.076)\end{array}$ & $\begin{array}{l}0.204 \\
(0.396)\end{array}$ & $\begin{array}{l}0.091 \\
(0.100)\end{array}$ & $\begin{array}{l}0.118 \\
(0.336)\end{array}$ \\
\hline $\mathrm{X} / \mathrm{GDP}$ & $\begin{array}{l}-0.036^{* *} \\
(0.015)\end{array}$ & $\begin{array}{l}-0.004 \\
(0.003)\end{array}$ & $\begin{array}{l}-0.024+ \\
(0.015)\end{array}$ & $\begin{array}{l}-0.005^{*} \\
(0.003)\end{array}$ & $\begin{array}{l}-0.034 * * \\
(0.016)\end{array}$ & $\begin{array}{l}-0.010 * * * \\
(0.004)\end{array}$ & $\begin{array}{l}-0.031^{*} \\
(0.017)\end{array}$ & $\begin{array}{l}-0.010 * * * \\
(0.003)\end{array}$ \\
\hline Ln (quality) & $\begin{array}{l}0.027 \\
(0.060)\end{array}$ & & $\begin{array}{l}0.055 \\
(0.064)\end{array}$ & & $\begin{array}{l}0.017 \\
(0.070)\end{array}$ & & $\begin{array}{l}0.027 \\
(0.072)\end{array}$ & \\
\hline X/GDP* Ln (quality) & $\begin{array}{l}0.004 * * \\
(0.002)\end{array}$ & & $\begin{array}{l}0.003+ \\
(0.002)\end{array}$ & & $\begin{array}{l}0.004 * * \\
(0.002)\end{array}$ & & $\begin{array}{l}0.003 * \\
(0.002)\end{array}$ & \\
\hline Variety & & $\begin{array}{l}-0.239 \\
(0.296)\end{array}$ & & $\begin{array}{l}-0.298 \\
(0.258)\end{array}$ & & $\begin{array}{l}-0.550 \\
(0.412)\end{array}$ & & $\begin{array}{l}-0.784 * * \\
(0.327)\end{array}$ \\
\hline $\mathrm{X} / \mathrm{GDP} *$ variety & & $\begin{array}{l}0.009+ \\
(0.006)\end{array}$ & & $\begin{array}{l}0.009 * \\
(0.005)\end{array}$ & & $\begin{array}{l}0.021 * * * \\
(0.007)\end{array}$ & & $\begin{array}{l}0.022 * * * \\
(0.006)\end{array}$ \\
\hline Constant & $\begin{array}{l}-0.048 \\
(0.624)\end{array}$ & $\begin{array}{l}-0.242 \\
(0.867)\end{array}$ & $\begin{array}{l}-0.365 \\
(0.702)\end{array}$ & $\begin{array}{l}-0.467 \\
(0.806)\end{array}$ & $\begin{array}{l}0.054 \\
(0.692)\end{array}$ & $\begin{array}{l}-0.363 \\
(1.609)\end{array}$ & $\begin{array}{l}0.075 \\
(0.708)\end{array}$ & $\begin{array}{l}-0.067 \\
(1.547)\end{array}$ \\
\hline Observations & 528 & 528 & 307 & 467 & 467 & 307 & 272 & 272 \\
\hline Number of panelid & 114 & 114 & 70 & 98 & 98 & 70 & 61 & 61 \\
\hline AR(2)test $p$-value & 0.735 & 0.850 & 0.785 & 0.965 & 0.765 & 0.366 & 0.715 & 0.291 \\
\hline Hansen test $p$-value & 0.493 & 0.699 & 0.950 & 0.737 & 0.705 & 0.961 & 0.967 & 0.796 \\
\hline
\end{tabular}

Estimation method: GMM system (Arellando and Bover, 1995; Blundell and Bond, 1998) with Windmeijer (2005) correction for small sample biais. Exogenous variables used as instruments are year dummies (Roodman, 2009) for the system.

Source: Authors' calculations. 


\begin{tabular}{|c|c|c|}
\hline Afghanistan & Gambia, The & Nigeria \\
\hline Albania & Georgia & Norway \\
\hline Algeria & Germany & Oman \\
\hline Antigua and Barbuda & Ghana & Pakistan \\
\hline Armenia & Greece & Panama \\
\hline Australia & Grenada & Papua New Guinea \\
\hline Austria & Guatemala & Paraguay \\
\hline Azerbaijan & Guinea & Peru \\
\hline Bahamas, The & Guinea-Bissau & Philippines \\
\hline Bahrain & Guyana & Poland \\
\hline Bangladesh & Honduras & Portugal \\
\hline Barbados & Hungary & Qatar \\
\hline Belarus & Iceland & Romania \\
\hline Belgium & India & Russian Federation \\
\hline Belize & Indonesia & Rwanda \\
\hline Benin & Iran, Islamic Rep. & Saudi Arabia \\
\hline Bermuda & Iraq & Senegal \\
\hline Bhutan & Ireland & Seychelles \\
\hline Bolivia & Israel & Sierra Leone \\
\hline Botswana & Italy & Slovak Republic \\
\hline Brunei Darussalam & Jamaica & Slovenia \\
\hline Bulgaria & Japan & Solomon Islands \\
\hline Burkina Faso & Jordan & South Africa \\
\hline Burundi & Kazakhstan & Spain \\
\hline Cabo Verde & Kenya & Sri Lanka \\
\hline Cambodia & Kiribati & St. Kitts and Nevis \\
\hline Cameroon & Korea, Rep. & St. Lucia \\
\hline Canada & Kuwait & St. Vincent and the Grenadines \\
\hline Central African Republic & Kyrgyz Republic & Sudan \\
\hline Chad & Lao PDR & Suriname \\
\hline Chile & Latvia & Swaziland \\
\hline China & Lebanon & Sweden \\
\hline Colombia & Lesotho & Switzerland \\
\hline Comoros & Liberia & Tajikistan \\
\hline Congo, Dem. Rep. & Libya & Tanzania \\
\hline Congo, Rep. & Lithuania & Thailand \\
\hline Costa Rica & Macao SAR, China & Timor-Leste \\
\hline Cote d'Ivoire & Macedonia, FYR & Togo \\
\hline Croatia & Madagascar & Tonga \\
\hline Cuba & Malawi & Trinidad and Tobago \\
\hline Cyprus & Malaysia & Tunisia \\
\hline Czech Republic & Maldives & Turkey \\
\hline Denmark & Mali & Turkmenistan \\
\hline Djibouti & Malta & Uganda \\
\hline Dominica & Mauritania & Ukraine \\
\hline Dominican Republic & Mauritius & United Arab Emirates \\
\hline Ecuador & Mexico & United Kingdom \\
\hline Egypt, Arab Rep. & Moldova & United States \\
\hline El Salvador & Mongolia & Uruguay \\
\hline Equatorial Guinea & Morocco & Uzbekistan \\
\hline Eritrea & Mozambique & Vanuatu \\
\hline Estonia & Namibia & Venezuela, RB \\
\hline Ethiopia & Nepal & Vietnam \\
\hline Fiji & Netherlands & Yemen, Rep. \\
\hline Finland & New Zealand & Zimbabwe \\
\hline France & Nicaragua & \\
\hline Gabon & Niger & \\
\hline
\end{tabular}


ANNEX B: List of countries below the threshold according to Table 2 column (3)

Afghanistan

Burundi

Burkina Faso

Central African Republic

Comoros

Cayman Islands

Ethiopia

Micronesia, Fed. Sts.

Gambia, The
Guinea-Bissau

Greenland

Guyana

Haiti

Kiribati

Mali

Malawi

New Caledonia

French Polynesia
Rwanda

Solomon Islands

Somalia

Tuvalu

Tanzania

Uganda

Vanuatu

Zimbabwe 
ANNEX C: List of countries below the threshold according to Table 2 column (5)

\section{Bhutan}

Central African Republic

Comoros

Djibouti

Eritrea

Faroe Islands

Micronesia, Fed. Sts.

Gambia, The

Guinea-Bissau
Grenada

Greenland

Kiribati

St. Kitts and Nevis

Marshall Islands

Northern Mariana Islands

Palau

Solomon Islands

Somalia
South Sudan

Sao Tome and Principe

Saint Maarten (Dutch part)

Tonga

Tuvalu

St. Vincent and the Grenadines

Vanuatu

Samoa 
ANNEX D: The GMM approach in details

Departing from this general model:

$y_{i, t}=\alpha y_{i, t-1}+\beta^{\prime} X_{i, t}+\tau_{t}+\eta_{i}+v_{i, t}$ for $i=, \ldots, \mathrm{N}$ and $t=2, \ldots, \mathrm{T}$

where

$\varepsilon_{i, t}=\eta_{i}+v_{i, t}$ has the standard error component structure:

$\mathrm{E}\left[\eta_{i}\right]=\mathrm{E}\left[v_{i, t}\right\rfloor=\mathrm{E}\left[\eta_{i} \cdot v_{i, t}\right\rfloor=0$ for $i=, \ldots, \mathrm{N}$ and $t=2, \ldots, \mathrm{T}$

$y$ is the dependent variable, $X$ is the vector of explanatory variables, $\eta_{i}$ and $\tau_{t}$ denote respectively unobserved country- and time-effects and $v_{i, t}$ is the idiosyncratic disturbance term.

We perform the following transformation to remove the unobserved individual effect:

$y_{i, t}-y_{i, t-1}=\alpha\left(y_{i, t-1}-y_{i, t-2}\right)+\beta^{\prime}\left(X_{i, t}-X_{i, t-1}\right)+\left(\tau_{t}-\tau_{t-1}\right)+\left(v_{i, t}-v_{i, t-1}\right)$

Nevertheless, instead of using a "first-difference transformation" as is usually done, we perform a "forward orthogonal deviation". Thus, instead of subtracting the previous observation from the contemporaneous one, we subtract the average of all future available observations of a variable ${ }^{5}$ This way of dealing with heterogeneity allows us to preserve sample size in our unbalanced panel while still being able to use past values of explanatory variables as instruments (Arellano and Bover, 1995; Roodman, 2009).

Under the assumption of absence of serial correlation in the idiosyncratic disturbance terms on the one hand:

$\mathrm{E}\left[v_{i, t}, v_{i, s}\right]=0$ for $i=1, \ldots, \mathrm{N}$ and $s \neq t$,

that the initial conditions are predetermined on the other hand:

$\mathrm{E}\left[y_{i, 1} \cdot v_{i, t}\right]=0$ for $i=, \ldots, \mathrm{N}$ and $t=2, \ldots, \mathrm{T}$,

the differenced equation ( $3 \mathrm{~d})$ can be instrumented by lagged levels of explanatory variables (Arellano and Bond 1991), using the following $m=0.5(T-1)(T-2)$ moment conditions:

$\mathrm{E}\left[y_{i, t-s} \cdot\left(v_{i, t}-v_{i, t-1}\right)\right]=0$

${ }^{5}$ That is, for a variable $w$ the transformation will be: $w_{i, t+1} \equiv c_{i t}\left(w_{i t}-\frac{1}{T_{i t}} \sum_{s\rangle t} w_{i s}\right)$ where the sum is taken over all available future observations $T_{i t}$, and the scale factor $c_{i t}$ is $\sqrt{T_{i t} /\left(T_{i t}+1\right)}$. 
$\mathrm{E}\left[X_{i, t-s} \cdot\left(v_{i, t}-v_{i, t-1}\right)\right]=0$

For $t=3, \ldots, \mathrm{T}$ and $s \geq 2$

Furthermore, according to Blundell and Bond (1998), when combining equations (1d) with two additional assumptions:

$E\left[\eta_{i} \cdot\left(y_{i, 2}-y_{i, 1}\right)\right]=0$

$E\left[\eta_{i} \cdot\left(X_{i, 2}-X_{i, 1}\right)\right]=0$ for $i=, \ldots, \mathrm{N}$

which are restrictions on the initial conditions of the data generating process ${ }^{6} ; T-2$ additional moment conditions can be used:

$$
\begin{aligned}
& \mathrm{E}\left[\varepsilon_{i, t} \cdot\left(y_{i, t-1}-y_{i, t-2}\right)\right]=0 \\
& \mathrm{E}\left[\varepsilon_{i, t} \cdot\left(X_{i, t-1}-X_{i, t-2}\right)\right]=0 \text { for } i=, \ldots, \mathrm{N} \text { and } t=3, \ldots, \mathrm{T}
\end{aligned}
$$

\footnotetext{
${ }^{6}$ In our context, assumptions ( $8 \mathrm{~d}$ and $9 \mathrm{~d}$ ) mean for example that deviations of $y_{i, 1}$ from long-run steady-state values must not depend on unobserved fixed-effects, even if the latest can affect the level of steady-state outputs. Bond et al. (2001) argue that these assumptions may be valid in growth model frameworks, thus allowing us to use the System-GMM estimator in our model.
} 
ANNEX E: The quality and variety indices

\section{The quality index}

The quality of the export basket is constructed following Hausmann et al. (2007). First, Hausmann et al. propose an index called PRODY that attributes a level of productivity to each $k$ (HS-6) line. The total exports for a country $i$ is,

$$
X_{i}=\sum_{k=1}^{n} x_{i k}
$$

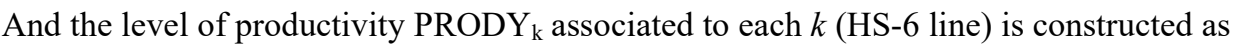

$P R O D Y_{k}=\sum_{i} \frac{\left(x_{i k} / X_{i}\right)}{\sum_{i}\left(x_{i k} / X_{i}\right)} Y_{i}$

where $\mathrm{Y}_{\mathrm{i}}$ is the GDP per capita in Purchasing Power Parity of each country $i, \sum_{i}\left(x_{i k} / X_{i}\right)$ is the sum of the share of product $k$ exported in all products.

This index is a variant of the Balassa's index of revealed comparative advantage. This way, exports from developed countries are considered as more productive that the ones coming from developing economies.

Finally, the level of productivity associated to the export basket of each country $i$ is,

$E X P Y_{i}=\sum_{k}\left(\frac{x_{i k}}{X_{i}}\right) P R O D Y_{k}$

Thus, it depends on the degree of concentration of the export basket, weighted by the quality of the products exported. The underlying idea behind this indicator is that diversifying its exports basket away from products of low productivity may accelerate subsequent growth. We compute a yearly EXPY $i$ indicator.

\section{The variety index}

In order to allow comparability of the index between countries and time, the export variety (or extensive margin of exports) is constructed following a modified version proposed by Feenstra and Kee (2008) of the Hummels and Klenow (2005) index.

Hummels and Klenow (2005) propose a measure of "extensive margin" of trade that is consistent with product variety for a CES function. This indicator can be defined as changes in exports that are due to changes in the number of goods (a change in the variety of products) rather than changes in the amount exported of each good. Besides the fact that this formula is consistent with trade theory, we choose it among all the definitions of extensive margin available in the literature review because it takes into account the importance of the traded good instead of roughly counting lines. 
The construction of the indicator is based on the idea that exports from countries $h$ and $F$ differ but have some products varieties in common. This common set is denoted by $J \equiv\left(J_{i t}^{h} \cap J_{i t}^{F}\right) \neq \varnothing$. An inverse measure of export variety from country $h$ will be defined by

$$
\lambda_{i t}^{h}(J) \equiv \frac{\sum_{j \in J} p_{i t}^{h}(j) q_{i t}^{h}(j)}{\sum_{j \in J_{i t}^{h}} p_{i t}^{h}(j) q_{i t}^{h}(j)}
$$

Therefore, the ratio $\left[\frac{\lambda_{i t}^{F}(J)}{\lambda_{i t}^{h}(J)}\right]$ measures the export variety of country $h$ relative to country $F$. It increases with the variety exported from country h, and decreases with the variety exported from country F. Thus, to be measured, this indicator needs a consistent comparison country F.

Feenstra and Kee (2008) use the worldwide exports from all countries to the United States (US) as benchmark. Indeed, US appear as the mayor partner in terms of imported variety (US imports almost 99\% of all the varieties existing) and provides highly disaggregated trade databases (until 10 digit codes). Nevertheless, as Feenstra and Kee (2008) noted, it would be preferable to use countries' worldwide exports instead of US imports. Indeed, this restriction makes the measure dependent to the import structure of the US. And for countries that export goods that have a small value in the import structure of this partner or that do not export some kind of varieties to it (mostly developing countries), the magnitude of their export variety will appear under-evaluated. Thus, in order to correct for these effects we prefer to work with the entire world as the benchmark $F$, as in Hummels and Klenow (2005), even if this forces us to use only HS-6 disaggregated trade data.

Moreover, we need a benchmark $F$ that doesn't change through time, in order to associate any variation in the indicator to a variation in the export variety of the country $h$. So, following Feenstra and Kee (2008) we take the union of all products sold in the world market in any year over the period 1988-2014, and we average real exports sales of each product over years. In this way, $J_{i}^{F} \equiv \cup_{h, t} J_{i t}^{h}$ is the total set of varieties imported by the entire world in sector $i$ over all years, and $p_{i}^{F}(j) q_{i}^{F}(j)$ is the average real value of world imports for product $j$ (summed over all source countries and averaged across years). Then, comparing country $h$ to the world $(F)$ allows us to set $\lambda_{i t}^{h}(J)=1$ and the export variety by country $h$ takes the form:

$$
\mathrm{A}_{i t}^{h} \equiv \frac{\lambda_{i t}^{F}(J)}{\lambda_{i t}^{h}(J)}=\frac{\sum_{j \in J_{i t}^{h}} p_{i t}^{F}(j) q_{i t}^{F}(j)}{\sum_{j \in J_{i}^{F}} p_{i}^{F}(j) q_{i}^{F}(j)}
$$

Thus, export variety only changes due to variations in the numerator, and thus, due to changes in the set of goods sold by the country $h$. This allows us to do comparison of export varieties across countries and over time. Moreover, this indicator goes beyond a simple count of trade lines, because it takes into account the relevance of the sector $i$ (HS-6 line) in world trade. 